\title{
Entrepreneurial Skills Required by Mechanical Engineering Craft Practice Trade Students in Technical Colleges in Kano State, Nigeria
}

\author{
MELE, E. F* CYRIL, M. U \& IBRAHIM, K. M \\ Department of Technology Education, Modibbo Adama University of Technology, Yola \\ Adamawa State, Nigeria
}

\begin{abstract}
The study identified Entrepreneurial Skills Required by Mechanical Engineering Craft Practice Trade Students in Technical Colleges in Kano State. The study was guided by two research questions. Two null hypotheses were formulated and tested at 0.05 level of significance. A descriptive survey research design was used for the study. The population of the study comprised of 44 entrepreneurs and 24 teachers making a total of 68 respondents. The entire population was used for the study. The instrument used for data collection was a 63 items structured questionnaire. The reliability coefficient of the instrument was 0.79. Mean, Standard Deviation, and Grand Mean were used to answer research questions $1 \& 2$. While z-test was used to test the hypotheses at 0.05 level of significance. The findings of the study revealed among others that, technical colleges' students of mechanical engineering craft practice trade require technical skills to operate various machines like; lathe, drilling, milling, shaping and band saw. All the hypotheses tested revealed that there is significant difference between the opinion of entrepreneurs and teachers on entrepreneurship skills required by mechanical engineering craft practice trade students in technical colleges in Kano state. Based on these findings the researchers recommend, among others, that; Entrepreneurship training should be given topmost priority. This would enable the students develop entrepreneurial technical skills and attitude necessary for gainful self or paid employment.
\end{abstract}

DOI: $10.7176 / \mathrm{JEP} / 10-27-08$

Publication date:September $30^{\text {th }} 2019$

\section{Introduction}

Technical colleges are established for training of students to acquire practical skills, knowledge and attitude, necessary for promotion of industrial development in the area of maintenance, production of goods and general technical services (Abdulkadir, 2011). Mechanical Engineering Craft Practice trade (MECPT)is one of the trades found in technical colleges, which is aimed at training and imparting necessary skills leading to the production of craftsmen who will be self-reliant and enterprising in job areas, such as Metal fitting, Machining, Welding and Fabrication [National Board of Technical Education (NBTE), 2008].

Furthermore, MECPT is a branch of engineering which deals with machines and mechanized processes, particularly power generation, transmission, utilization of tools and equipment (Atsumbe, Okoro, \& Ogwo, 2012).MECPT students are usually awarded the National Technical Certificate (NTC) by National Business and Technical Examination Board (NABTEB) after successfully passing all the relevant modules of the course, which includes entrepreneurship skills training.

Entrepreneurship is the process of creating new enterprises to meet new challenges and opportunities in a community(Igweh, 2005 and Ubale, 2010).Entrepreneurship is a process of identifying and starting business venture and involves the acquisition of skills, ideas, managerial competences, sourcing and organizing the required resources and taking both the risks and rewards associated with the venture(Allawadi, 2007. In its contribution to emerging definitions, the National Universities Commission, (NUC, in Oviawe, 2010) defined entrepreneurship as the art which involves recognizing a business opportunity, mobilizing resources and persisting to exploit that opportunity. Similarly, Enu \& Esu (2011) considered entrepreneurship as the ability to seek investment opportunities and establish an enterprise based on identified opportunities. The term entrepreneurship is derived from the word "entrepreneur", the process of becoming an entrepreneur, is simply the act of being an entrepreneur.

An entrepreneur is someone who chooses or assumes risk, identifies business opportunities, gathers resources, initiates actions and establishes an organization or enterprise to meet such "demand or market opportunity (Anyakoha, 2006 and Ubale, 2010). An entrepreneur in MECPT is someone who established mechanical engineering related business, manages it to grow and become profitable, or one takes over an existing business with the purpose of introducing new products and services or developing new source of materials and continue to build and innovate on it (Anyokoha, 2006). Skill is thought of as a quality of performance which does not depend solely upon a person's fundamental, innate capacities but must be developed through training, practice and experience (Chell, 2013).

There are many entrepreneurial skills that must be acquired by every prospective entrepreneur. These skills 
includes; Technical, Managerial, Communication, Marketing and Accounting skills. This proper dwelled only on Technical and Managerial Skills, Managerial skills can be acquired, either personally or through the employment of others. The very valuable attributes of innovation and involvement can paradoxically work against group operation demanded in managerial terms. Hence, it is vital that an entrepreneur develops his managerial skills to set alongside his innovative capabilities, if the entrepreneur is to succeed in Planning, Organizing, Coordinating, Establishing, Delegating, Directing, Controlling and Setting of business enterprise.

Technical skills are the knowledge and abilities needed to accomplish specific tasks relating to mechanical engineering craft practice such as observing safety precaution, Ability to use lathe machine, ability to select appropriate tools, ability to use drilling machine. Well-trained craftsmen in MECPT in technical colleges can only be achieved when both the entrepreneurship skills are given to students before graduation. However, most of the so called craftsmen that graduated from technical colleges, cannot employ themselves nor are they being employed perhaps it is because they do not have necessary employable entrepreneurial skills (Anthony, Saidu, Muhammed, \& Junguru, 2009). Therefore, it is against this background that the researchers attempted to find out the entrepreneurship skills required by mechanical engineering craft practice trade students in technical colleges in Kano state.

\subsection{Statement of the Problem}

Enrolment in Technical colleges in Kano state is increasing day-by-day and this also increases the number of unemployed graduates in the state, [Kano State Government (KNSG), 2011]. One of the main causes of unemployment of technical college student is perhaps lack of required entrepreneurial skills. Graduates unemployment problem has generated several socio-economic problems in the country manifesting in the following: militancy in the Niger Delta, political thuggery among youths, increased rate of armed robbery, kidnapping, prostitution and even the Boko Haram saga (Ibe, 2012).There is need to look at the most potent way out of this problem. One of the strategies that can help in solving the problem of unemployment among students is entrepreneurial skills (Ubale, 2010). This position implies that, acquisition of entrepreneurial skills by MECPT students in technical colleges will help fill the wide gap of unemployment, created by absence of required entrepreneurial skills among the students. The problem of this study is therefore meant to identify the entrepreneurial skills required by mechanical engineering craft practice trade students in technical colleges in Kano state, with a view of recommending their implementation to the benefit of the students parents and society at large.

\subsection{Purpose of the Study}

The major purpose of this study was to identify Entrepreneurial Skills Required by MECPT Students in Technical Colleges in Kano State that could enable the graduates establish mechanical trade enterprises. Specifically, the Study:

1. Identified the technical skills required by MECPT students in technical colleges in Kano state for establishing mechanical trade enterprise.

2. Identified the managerial skills required by MECPT students in technical colleges in Kano state for establishing mechanical trade enterprise.

\subsection{Research Questions}

The following research questions were asked to guide the study.

1. What are the technical skills required by MECPT students in technical colleges in Kano state for establishing mechanical trade enterprise?

2. What are the managerial skills required by MECPT students in technical colleges in Kano state for establishing mechanical trade enterprise?

\subsection{Hypotheses}

The following null hypotheses were formulated and tested at 0.05 level of significance:

$\mathrm{HO}_{1}$ There is no significant difference between the mean responses of MECPT entrepreneurs and teachers on the technical skills required by mechanical engineering craft practice trade students in technical colleges in Kano state for establishing mechanical trade enterprise.

$\mathrm{HO}_{2}$ There is no significant difference between the mean responses of MECPT entrepreneurs and teachers on the managerial skills required by MECPT students in technical colleges in Kano state for establishing mechanical trade enterprise.

\subsection{Significance of the Study}

The result of this study is of significant benefit to the teachers, students, science and technical schools boards, researcher's government and society in general. It is hoped that the result of this study will provide information to 
teachers on entrepreneurship skills required by MECPT students in technical colleges for establishing mechanical enterprise. It will also make teachers willing to attend training and re-training programmes on entrepreneurship education for improvement and efficiency in teaching entrepreneurial skills. The study will help students of MECPT acquire basic entrepreneurship skills that are required for establishing mechanical enterprise. It will also help them remove entrepreneurship phobia and increase their chances of trying out self-employment. This information may be used by the science and technical schools board to organize short training courses for MECPT teachers on entrepreneurship education. The study will also be beneficial to researchers in the educational sector, as it will add to the already existing knowledge of require entrepreneurship skills, and serve as resource material to researchers.

\section{Methodology}

Descriptive survey was used as research design. According to Abdullahi, Ojulariand Jadas (2015), descriptive survey research design is systematic and unbiased investigation, which is concerned with the collection of data for the purpose of describing and interpreting existing conditions, prevailing practices, beliefs, attitudes and procedures. This study fits into descriptive survey design in the sense that, it aimed at collecting data from a representative sample of entrepreneur's and teachers of mechanical engineering craft practice trade in technical colleges in Kano State. The study was carried out in Kano State of Nigeria. The geographical region of the state is located between the latitude $11^{\circ} 59^{\prime} 47^{\prime}$ N $\mathrm{N}$ and longitudes $8^{\circ} 31^{\prime} 0^{\prime \prime} \mathrm{E}$ of the Greenwich Meridian (World Atlas Map, 2015). Kano state shares border will Katsina State to the north-west; Jigawa State to the north-east; Bauchi state to the south-east and Kaduna State to the south-west. The population of this study was 68 people. It comprised of 44 Entrepreneurs and24teachers of MECPT in technical colleges in Kano state. The population of this study is not large, so there was no sample because the entire population was used in the study. The instrument for data collection was a researchers' designed questionnaire tagged "Entrepreneurial Skills Required by Mechanical Engineering Craft Practice Trade Student in Technical Colleges (ESRMECPTSTCKSQ). The instrument contained 63 items. The questionnaire was divided into two sections, A, B. Section A elicited responses on Technical Skills Required. While Section B, elicited responses on Managerial Skills Required. The instrument was developed using five points rating scale. The response options and their assigned numerical values are as follows: Highly Required $(H R)=5$ points: Required $(R)=4$ points; Moderately Required $(M R)=3$ points: Not Required $(\mathrm{NR})=2$ points; Highly Not Required $(\mathrm{HNR})=1$ point.

The instrument underwent face validation only. Three experts, two from Vocational Education Department Modibbo Adama University of Technology, Yola and one expert from Science and Technical Education Department Bayero University, Kano, validated the instrument. The reliability of the instrument was determined using split-half method. The instrument was trial-tested on 12 Entrepreneurs and 8 Teachers of mechanical engineering craft practice trades from Technical Colleges in Jigawa state which did not form part of the population of the study. Pearson Product Moment Correlation Coefficient was used to correlate the result of the two halves. The reliability index of the instrument was found to be 0.79 .

The instrument was distributed directly to the respondents by the researchers with the help of one research assistant from each technical college visited. The instruments were retrieved the same way they were distributed within a period of three days to enhance high percentage of return. The data collected was analyzed using Microsoft Excel. Mean and standard deviation was used to answer the research questions, while z-test was used to test the null hypotheses at 0.05 level of significance. The grand mean of the items in each of the research questions was computed by adding scores in each category. Real limits of the assigned numerical values to the response options were used to determine the cut off points for interpreting and taking decision when answering the research questions. The mean of the assigned numerical values to the response options $5+4+3+2+1 / 5$ is 3.00 . For this study, the researchers decided to use the upper limit of 3.00 which is 3.50 .

Therefore the decision Rule is that, any Item with a mean response of 3.50 and above was considered as Required Skills, while those with a mean below 3.50 was considered as Not Required Skills. The choice of z-test was appropriate for this study because according to Uzoagulu (2011), z-test is used for analyzing data whose sample size is thirty and above $(\geq 30)$. The present study used large sample of more than 30 , therefore $z$-test was considered appropriate. The decision rule for testing the hypothesis was that, if $z$-calculated value is greater than $\mathrm{z}$ - critical value, the null hypothesis was rejected and if $\mathrm{z}$-calculated value is less than $\mathrm{z}$ - critical value, the null hypothesis was accepted.

\section{Result}

This section Presents summary of the analyses of the data collected. Mean, standard deviation and z-test were used in the analysis and the results are tabulated. Each table contains information on the responses to the research questions and hypotheses.

\section{Research question 1}

What are the technical skills required by mechanical engineering craft practice trade students in technical 
colleges in Kano state for establishing mechanical enterprise?

Table 1: Mean Ratings and Standard Deviations of Opinion of Entrepreneurs and Teachers on Technical Skills Required by Mechanical Engineering Craft Practice Trade Students for Establishing Mechanical Enterprises

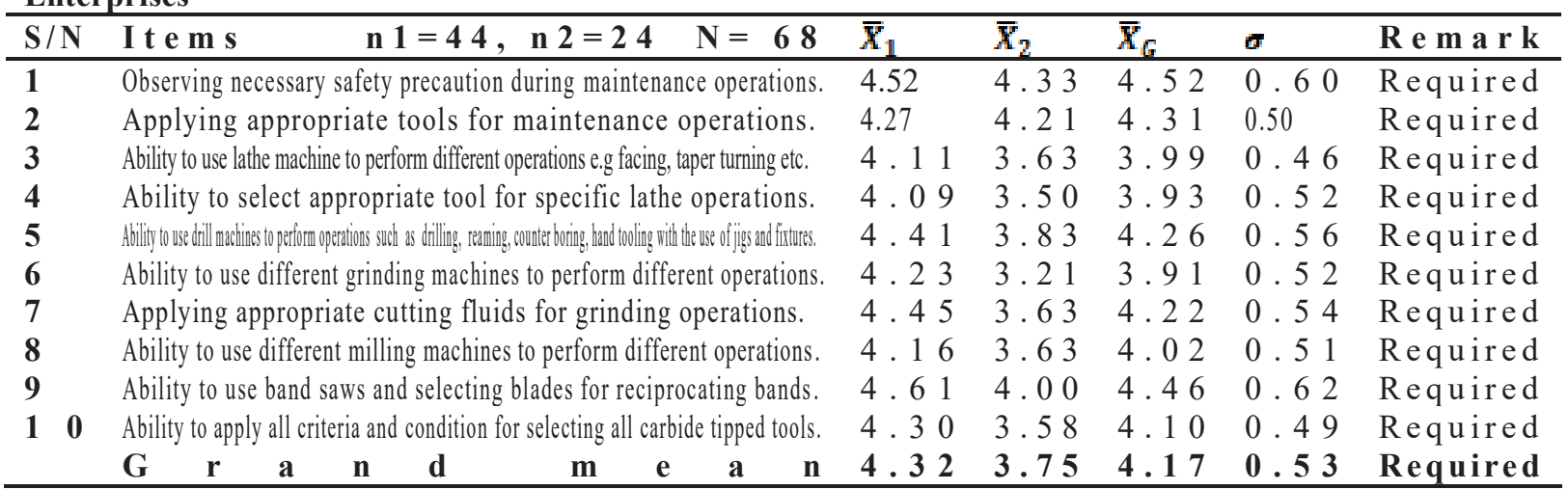

Key: $\bar{X}_{1}=$ entrepreneurs $\bar{X}_{2}$ teachers $=\bar{X}_{G}=$ Grand mean of items, $\sigma=$ standard deviation,

$\mathrm{n} 1=$ number of entrepreneurs $\mathrm{n} 2=$ number of teachers

Table 1 revealed that MECPT students require the ability to use and operate various machines like (lathe, drilling, milling, shaping, and band sawing). This is because each item had average mean score of the two groups of respondents ranging between 3.91 to 4.52 which are above this study's decision cut-off point. The responses of the two groups of respondents look similar to each other by having almost the same opinion on all the ten items. The result indicates that technical skills are required by mechanical engineering craft practice trade students for establishing mechanical enterprise. The standard deviation of the two groups of respondents showed close but different ranges with each having a standard deviation below 0.62 . This indicate that, the opinion of the respondents were closely unanimous. Based on the unanimous result presented, one can conclude that, technical skills are required by mechanical engineering craft practice students in technical colleges in Kano state for establishing mechanical enterprise.

\section{Research question 2}

What are the managerial skills required by (MECPT) students in technical colleges in Kano state for establishing mechanical trade enterprise?

Table 2: Mean Ratings and Standard Deviations of Opinion of Entrepreneurs and Teachers on Managerial Skills Required by Mechanical Engineering Craft Practice Trade Students for Establishing Mechanical Enterprises

\begin{tabular}{|c|c|c|c|c|c|c|c|}
\hline $\mathbf{S} / 1$ & $\mathbf{N}$ & I t e m s n $1=44, \quad$ n $2=24$ & $\bar{X}_{1}$ & $\bar{X}_{2}$ & $\bar{X}_{G}$ & $\sigma$ & $\mathbf{R}$ e $\mathbf{m}$ a $\mathbf{r}$ k \\
\hline 1 & 1 & effectively for goal attainment. & 4.52 & 3.54 & 4.23 & 0.61 & Required \\
\hline 1 & 2 & Implementing plan for goal attainment. & 61 & 4.04 & 4.40 & 0.60 & i red \\
\hline 1 & 3 & Coordinating office duties effectively & 25 & 3.88 & 4.17 & 0.51 & i red \\
\hline 1 & 4 & Establishing and maintaining good purchasing policy for the rightht tools, equipment and material for operating enterprise. & 27 & 3.58 & 4.17 & 50 & i r e d \\
\hline 1 & 5 & Delegating authority to employees. & 75 & 3.50 & 3.71 & 0.46 & i r e d \\
\hline 1 & 6 & Direct affairs of enterprise & 55 & 3.29 & 3.50 & 0.44 & $\mathrm{Re}$ \\
\hline 1 & 7 & Controlling affairs of the enterprise. & 4.27 & 3.21 & 3.94 & 0.50 & R e quired \\
\hline 1 & 8 & realistic business target for an enterprise. & 4.05 & 3.58 & 3.94 & 0.48 & Re quired \\
\hline 1 & 9 & Organizing material resources for managing an enterprise. & 4.23 & 3.63 & 4.10 & 0.50 & Re quired \\
\hline 2 & $\mathbf{0}$ & Organizing human resources for managing an enterprise & 4.27 & 3.63 & 4.10 & 0.51 & Re quired \\
\hline & & G & . 18 & 3.17 & 4.07 & 0.51 & $R$ e qu i r e d \\
\hline
\end{tabular}

Key: $\quad$ Key: $\bar{X}_{1}=$ entrepreneurs $\bar{X}_{2}$ teachers $=\bar{X}_{G}=$ Grand mean of items, $\sigma$ =standard deviation,

$\mathrm{n} 1=$ number of entrepreneurs $\mathrm{n} 2=$ number of teachers

Table 2 revealed that, the 10 items received mean response between 3.21 to 4.52. Only item 17 had low opinion of the teachers of 3.21. This should have been rejected as required since it isbelow the cut-off point. However, the mean of responses of both groups of respondents is 3.94, so it was accepted as required item. The grand standard deviation also showed that just as was seen under Research Question 1, the two groups of respondents have a lower grand standard deviation ranging from 0.44 to 0.67 indicating that, majority of the respondents agree on the same items. The grand mean of the two groups shows 4.07. The two groups of respondents have similar opinion in almost all the items. Based on the data presented and the analysis done, one can conclude that all ten items under the research question 2 are required by mechanical engineering craft practice students in technical colleges in Kano state for establishing mechanical enterprise. 


\section{Hypothesis 1}

There is no significant difference in the mean opinion of entrepreneurs and teachers on the technical skills required by MECPT students in technical colleges in Kano state for establishing mechanical enterprises

Table 6: Z-Test Analysis of Difference between Opinion of Entrepreneurs and Teachers on Technical Skills Required.

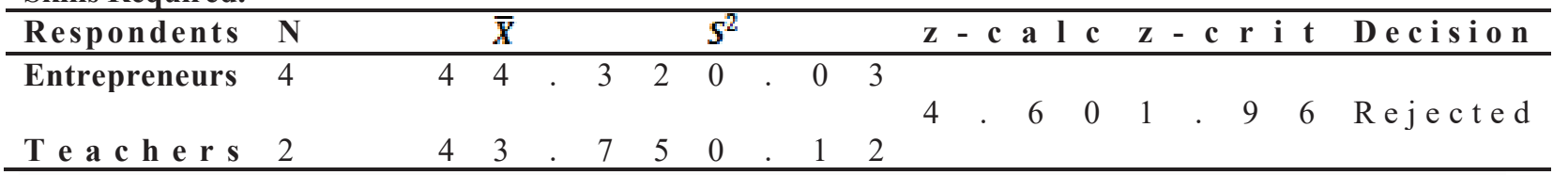

Table 6 revealed that $\mathrm{z}$-cal (4.60) was less than the $\mathrm{z}$-crit (1.96) at 0.05 level of significance. Therefore, the null hypothesis was rejected indicating that, there is significant difference between the mean response of entrepreneurs and teachers on the technical skills required by MECPT students in technical colleges in Kano state for establishing mechanical enterprise.

\section{Hypotheses 2}

There is no significant difference in the mean opinion of entrepreneurs and teachers on the managerial skills required by mechanical engineering craft practice students in technical colleges in Kano state for establishing mechanical enterprise.

Table 7: Z-test Analysis of Difference between Opinion of Entrepreneurs and Teachers on Managerial Skills Required.

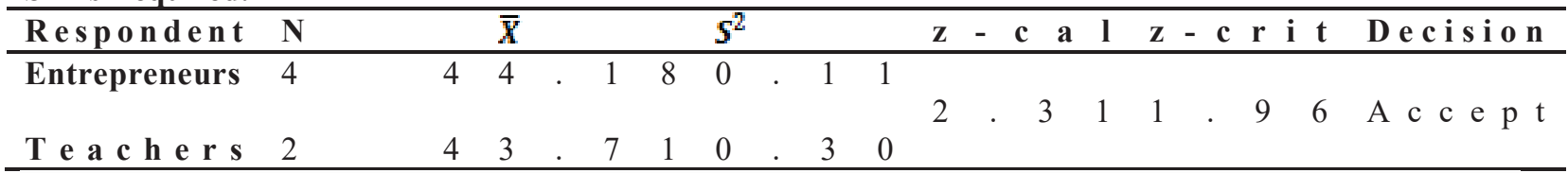

Table 7 revealed the opinion of entrepreneurs and teachers on managerial skills required was tested statistically with a z-test at 0.05 level of significance. Although the data showed that $\mathrm{z}$-cal (2.31) was greater than the $\mathrm{z}$-crit (1.96) at 0.05 level of significance, but the difference is not significant Therefore, the null hypothesis was accepted indicating that there is no significant difference between the mean responses of entrepreneurs and teachers on managerial skills required by mechanical engineering craft practice students in technical colleges in Kano state for establishing mechanical enterprise.

\section{Findings}

Based on the results obtained from the analyzed data, with respect to two research questions and two null hypotheses that guided this study, the following are the findings of the study.

1. Technical college students of mechanical engineering craft practice trade require the ability to use and operate various machines like; lathe, drilling, milling, shaping, and band sawing machines as technical skills for establishing mechanical trade enterprise in Kano state.

2. Managerial skills like; planning, organizing, controlling, coordinating, delegating, implementing, establishing, setting and directing are all required by mechanical engineering craft practice trade students in technical college in Kano state for establishing mechanical trade enterprise.

3. There is significant difference between the mean opinion of entrepreneurs and teachers on technical skills required by mechanical engineering craft practice trade students in technical colleges in Kano state for establishing mechanical enterprise.

4. There is no significant difference between the mean opinion of entrepreneurs and teachers on managerial skills required by mechanical engineering craft practice trade students in technical colleges in Kano state for establishing mechanical enterprise.

\subsection{Discussion}

The findings of the study were discussed based on the pattern the research questions and hypotheses were presented in this study. The findings of research question 1, that sought the opinion of respondents as technical skills revealed that technical college students of MECPT required all the technical skills, necessary to establish mechanical trade enterprise. This finding is in agreement with the findings of (Ubale, 2010 and Musa, 2015) who found out that emerging technical competencies are needed for establishing automobile and mechanical enterprises. Also it is in line with the findings of Ifeanyieze and Nwodo, (2010) who identified 98 technical skills required for rabbit production. These entrepreneurship skills will support the income of teachers of agricultural science.

The findings of this study regarding managerial skills in research questions 2 revealed that, the students of mechanical engineering craft practice trade in technical colleges require entrepreneurial managerial skills like: planning, organizing, controlling, coordinating, delegating, implementing, setting and directing an enterprise. 
This is in tandem with the findings of (Atsumbe et al, 2012 and Agada, 2014) who found out that managerial skills are needed by technical college students of radio and television for establishing small and medium scale enterprises. This is also in line with the findings of Ubale (2012) who identified managerial competencies as one of the important competencies needed by vocational technical teachers and students to become entrepreneurs. Furthermore, the outcome of this study affirmed the findings of (Chell, 2013 and Oluka, 2016) who found out that electrical/electronic graduate of technology education needed managerial competencies for self-employment. Findings on hypothesis 1 revealed that, the null hypothesis was rejected indicating that, there is no significant difference between the mean response of entrepreneurs and teachers on the technical skills required by mechanical engineering craft practice trade students in technical colleges in Kano state for establishing mechanical enterprise. This implies that both the entrepreneurs and the teachers have similar view on the technical skills required by students for establishing mechanical enterprise. This is in conformity with the findings of Oluka (2016) who found out that electrical/electronic graduate of technology education needed technical competencies for self-employment in Enugu state. Any observed difference is statistically significant.

Findings on hypothesis 2 shows that, there is significant difference between the mean responses of entrepreneurs and teachers on managerial skills required by mechanical engineering craft practice trade students in technical colleges in Kano state for establishing mechanical enterprise. This is most likely due to the fact that the managerial skills obtained in the technical colleges might not be similar to what is obtained in the management of enterprise. This corroborates the findings of Ubale, (2012) who found out that the managerial skills are desirable for vocational technical teacher students to become entrepreneurs.

\section{Conclusion}

Based on the findings of this study, the researchers concluded that mechanical engineering craft practice trade students in technical colleges in Kano state, require technical skills such as; the ability to operate various machines such as: lathe, drilling, milling, shaping, and band sawing machines. Also, the students require. Managerial skills, like; planning, organizing, controlling, coordinating, delegating, implementing, setting and directing for success in establishing and sustaining mechanical trade enterprise after graduation.

\subsection{Recommendations}

Based on the findings of the study, the following recommendations are made:

1. Entrepreneurship education should be given topmost priority by government through schools. This would enable the students to become equipped with entrepreneurial skills that would be useful to them after graduation.

2. All entrepreneurial skills identified in this study should be packaged and incorporated into mechanical engineering craft practice trade curriculum module for training students of technical colleges.

3. Teachers of mechanical engineering craft practice trade in technical colleges should be exposed to new content of the subject and adequate training and retraining on Technical and managerial skills entrepreneurial skills required by technical college students.

\subsection{Implication of the Study}

The implication of this study is that, since the identified entrepreneurial skills such as technical and managerial skills are required by technical college students, there is need for the students to be taught these skills otherwise they will continue to be facing challenges of dependency on employment providers equipping students with entrepreneurial skills is the only strategy that will make products of technical colleges become self-employed and be able to employ others.

\section{References}

Abdulkadir, M. (2011).Assessment of teaching -learning practices in practical motor vehicle mechanics work at technical college level in Niger State.(Unpublished M. Tech thesis.Federal University of Technology Minna Nigeria).

Agada, G. (2014).Entrepreneurial skills needed by technical College students for establishing Radio and Television small and medium scale enterprise in Kogi state. (Unpublished Master's Thesis, University of Nigeria, Nsukka.)

Allawadi, S.C. (2007).Entrepreneurship Challenges in the $21^{\text {st }}$ century. Indian Institutes of Materials management. International Journal of Humanities and Social Science 3(5), 204-211.

Anthony, C. Saidu, M. Muhammed, V. \&Junguru, F. (2009). Developing entrepreneurial Skills in youth through information and communication technology.A proceedings of Science Teachers Association of Nigeria $50^{\text {th }}$ Annual Conference, 3, 62-65

Anyakoha, E.U. (2006). Practical tips for Economic Empowerment and survival.Nsukka: AP Express.

Atsumbe, B. N. Okoro, O. M \&Ogwo, B. A. (2012).Practical Skill Improvement Needs of Technical College 
Mechanical Engineering Craft Practice Curriculum in Nigeria. Journal of Education and Vocational Research 3(4), 118-126.

Chell, E. (2013).Review of skill and the entrepreneurial process. International Journal of Entrepreneurial Behaviour and Research, 19(1), 6-31

Enu, D. B. \&Esu, A. E. O. (2011). Re-Engineering Values Education in Nigerian Schools As Catalyst for National Development.International Education Studies, 4, 1.

Federal Republic of Nigeria, (2013). National Policy on Education (revised), Lagos, Federal Government press.

Ibe, E.O. (2012). Re-engineering entrepreneurial education for employment and self Productivity in Nigeria. Knowledge Review, 26 (1), 1-6.

Ifeanyize, F.O. \&Nwodo, F.O. (2010). Entrepreneurship skills support business in rabbit production for enhancing the income of teachers of agriculture in Enugu state. A Proceeding of Science Teachers Association of Nigeria.50 ${ }^{\text {th }}$ Annual conference, 2009.

Igweh, A. U. (2005). Entrepreneurship Education in Technology Programme: A panacea for sustainable youth empowerment in Nigeria in proceedings of the 1st Annual National Conference of Nigerian Association of Teachers of Technology (NATT). Lagos: Rothemed International Ltd.

Kano State Government. (2011). Kano State ministry of education: educational sector programme. Retrieved from teachers guide magazine. September, 15. 2011.

Musa, J. D. (2015). Perceived entrepreneurial competencies required by automobile Technology students in technical colleges in Bauchi and Gombe state. (Unpublished Master's thesis, Modibbo Adama University of Technology Yola, Nigeria.)

National Board for Technical Education NBTE, (2008).Mechanical engineering craft curriculum and Module specifications: National Technical Certificate (NTC) and Advanced National Technical Certificate (ANTC).UNESCO-Nigeria Project. Retrieved May 15, 2014.

Oluka, S.N. (2016). Entrepreneurial Competency Needed by Electrical/Electronic graduates of Technology Education for Self-employment in Enugu state. British journal of education European centre for research training and development UK. 14(8), $117-125$.

Oviawe, J. I. (2010). Repositioning Nigerian Youths for Economic Empowerment through Entrepreneurship Education. European Journal of Education Studies. 2(2), 22-30.

Oyeku, O.M. Oduyoye, O.O. Elemo, G.N. Akindoju A.F. Karimu, F.A .Unuigbe, K.O (2015). Chemistry Entrepreneurship for Small and Medium Enterprises Development: A Panacea for Job and Wealth Creation. Industrial Engineering Letters. 5(4), 20-35.

Ubale, C.M. (2010). Entrepreneurship competencies needed by higher vocational technical education students in north eastern Nigeria. (Unpublished Ph.D. Thesis, Federal University of Technology Yola, Nigeria.)

Ubale, C.M. (2012). Marketing entrepreneurial competencies needed by higher vocational technical education students in north eastern geo-political zones, Nigeria. Ahmadu Bello university journal of vocational studies (ABUJVS). 6(1), 46-50.

Uzoagulu, A.E. (2011). Practical Guide to Writing Research Project Report in Tertiary Institutions. Enugu: John Jacob Classic publishers.

World Atlas Map, (2015). Latitude and longitude of Kano state Nigeria http://www.news Trcindia.com/information/worldinfor/latitudelongitude/countrycities/Nigeria/city-kano 1638346.htm. 